\title{
Minoritets- beskatning - et værktøj til at forstå opretholdelse af strukturelle uligheder i dansk akademia
}

\author{
Af Tess S. Skadegård Thorsen
}

\begin{abstract}
Minority Taxation - a Tool for Understanding the Maintenance of Structural Inequality in Danish Academia

Denmark has a strong tradition for doing critical analyses of the gendered inequalities of Danish academia - a critique that is particularly critical of gendered hiring practices. As such, Danish gender research has long grappled with the meta-scientific theories of positionality we recognize from e.g. Donna Haraway and Eve Sedgwick. However studies have yet to be conducted of the implicit and indirect inequalities that occur in the academic day-to-day experiences of researchers who are minoritized in more ways than their gender. Taking its point of departure in autoethnographic vignettes created during 3 years as a research-employee (PhD Fellow) as well as 7 years of teaching and supervising at 3 Danish universities, this article argues that Minority Taxation, a proposed Danish derivative of the US term Cultural Taxation (Padilla 1994), is a useful analytical tool for understanding the everyday experiences of structural inequalities in Danish academia. Minority Taxation covers both the concrete and affective extra-work minoritized academics are 'taxed with' performing due to structural inequalities. Deeming this form of work a tax aids in making more palpable the inequalities that can often seem hard to understand, quantify or negotiate.
\end{abstract}

\section{KEYWORDS}

Minority taxation, cultural taxation, decoloniality, academia, intersectionality

Tess S. Skadegård Thorsen er PhD stipendiat ved Aalborg Universitet. Hendes forskningsprojekt undersøger repræsentationspraksisser i dansk film og er en del af det Velux-financierede projekt A Study of Experiences and Resistances to Racialization (SERR). Tess er aktiv i studenterorganisationen FRONT. 


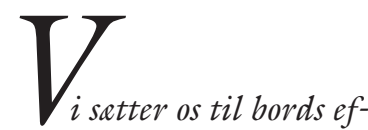

ter at have fyldt tallerkenerne med arets forste julesild, rejer, laks og andet godt fra de klassiske nordiske juleborde. Jeg er nyansat og det er min forste fallesfrokost med kollegaerne som $\mathrm{PhD}$ stipendiat. Vi taler om hvad der bragte os hver iser ind $i$ vores forskningsprojekter, og ind $i$ akademia. Jeg forsker i representation, diskrimination og racialisering $i$ dansk film, sa da en overordnet kollega sporger mig står jeg med et valg imellem at frembove min akademiske interesse eller mine levede erfaringer. Jeg satser på det sidste: måske er det et godt udgangspunkt for at vi kan leve hinanden at kende personligt. Jeg beskriver den diskrimination jeg har oplevet $i$ bornehave og folkeskole, og op igennem systemet indtil jeg fik min kandidat. De forste par eksempler lader ikke til at tilfredsstille hende, og hun sporger yderligere ind til mine oplevelser. Jeg gàr ikke i mange detaljer, men taler om hvordan vi blev opfordret til at tegne karikerede sorte ansigter $i$ bornehaven og hoor flittigt $N$-ordet blev brugt $i$ de institutioner jeg blev skolet $i$. Jeg velger ikke at beskrive den systematiske udelukkelse jeg har oplevet, den direkte og voldelige diskrimination jeg kender så intimt. Màske fordi jeg ved, at den vil positionere mig svagt i forhold til nye kollegaer, eller måske fordi jeg ikke har lyst til at lukke dem belt derind endnu, eller maske vil jeg ikke vere killjoy, eller maiske fordi jeg ikke har lyst til at kun den slags diskrimination, der er lettest at fole på, skal vere i centrum.

Det er ubehageligt at jeg allerede $i$ mine beskrivelser betvivles, så jeg giver detaljer, eksempler og gair $i$ dybden med hvor, hvornair og hvordan jeg har oplevet diskrimination. Min (overordnede) kollega er overrasket. Selvom vi alle berorer diskrimination, racialisering, racisme, diversitet og andetgorelse $i$ vores forskning, svarer kollegaen at det "lyder usandsynligt”. Hun fortsetter med at beskrive at hun under hendes skolegang og opvekst aldrig har oplevet den slags, selvom hun har et fremmedklingende navn. Da jeg siger, at det måske har en indvirkning om man leses som bvid eller ej, forteller hun mig, at hun altså ikke så min hudfarve forste gang hun modte mig og at hun ikke ser farve på den måde. Jeg er ny $i$ denne gruppe mennesker, jeg er den eneste, der ikke har kendt de andre på forhaind, og jeg foler mig mest af alt overrasket $i$ ojeblikket. Jeg rammes af 'imposter syndrome'. Jeg har ikke ord for, hvad jeg har oplevet, og er mest af alt frustrevet over, at jeg ikke ved, om det er mig eller dem, der haindterede situationen forkert.

I denne artikel introduceres begrebet minoritetsbeskatning som et analyseværktøj til undersøgelse af hverdags-oplevelser af strukturelle uligheder $\mathrm{i}$ det danske forskningsmiljø. Begrebet er en fordanskning og opdatering af det amerikanske begreb Cultural Taxation (Padilla 1994). Ovenstående vignette er den første rekonstruerede hændelse, der påbegyndte et autoetnografisk sideprojekt til mit $\mathrm{PhD}$-forskningsprojekt. Da jeg skrev oplevelsen ned i mine noter stod der blot:

"Når en forsker, som er min overordnede, gentagne gange spørger ind til min personlige oplevelse af diskrimination i Danmark for derefter at underminere den ved at påstå at de ting lyder helt usandsynlige, og at det har hun da aldrig oplevet, og hun har ellers et fremmedklingende navn (hun er hvid).

Da samme forsker fortæller mig at hun altså ikke så min hudfarve første gang hun mødte mig, og at hun ikke ser farve på den måde." (Logbog, 2016)

Med disse to sætninger vidste jeg ikke, at jeg havde påbegyndt en autoetnografisk noteringspraksis for at aflæse, registrere, nedfælde og behandle de diskriminerende og strukturelt undertrykkende mekanismer, som ville blive en konstituerende del af min hverdag som forsker. Jeg vidste kun, at det føltes forkert, grænseoverskridende, og at 
jeg nok ikke var alene med denne slags hændelser, når jeg, trods alt, var omgivet af forskere, der beskæftigede sig med netop racialisering, undertrykkelse, diskrimination, køn osv. De næste tre år ændrede min rapporterings- og skrivepraksis sig. Sideløbende med at jeg nedfrldede mere fyldestgørende og detaljerede beskrivelser af mine oplevelser, blev jeg også bedre til at mærke, forstå og beskrive oplevelsernes virkning på mig på en 'xrlig' måde (Toyosaki et al. 2009).

Denne artikel kortlægger først den autoetnografiske metode og dennes anvendelighed $\mathrm{i}$ forhold til at anskueliggøre og blotlægge strukturelle og systemiske diskriminationsformer, mikroaggressioner og undertrykkelsesmekanismer. Dernæst fremlægges fem eksempler, der viser forskellige nuancer af det, begrebet minoritetsbeskatning tillader at fremanalysere. De fem eksempler, ekstraarbejde, manglende feedback, mikroaggressioner/hverdagsracisme, tokenisering og emotionelt ekstraarbejde, falder indenfor to overordnede kategorier. Den ene, som jeg kalder konkretisérbar minoritetsbeskatning, tæller de første to eksempler, og indbefatter de let målbare konsekvenser strukturel diskrimination (Skadegård 2014; 2017) har på personer, som er marginaliserede i dansk akademia. Den anden kategori, affektiv eller emotionel minoritetsbeskatning, omhandler de former, som er svære at måle på, konkretisere eller anskueliggøre.

Artiklen illustrerer, hvordan strukturel diskrimination kan blive hverdag for en ung brun kvinde i det danske forskningsmiljø. Den påpeger således først og fremmest centrale måder, hvorpå minoritetsbeskatning påvirker minoriserede juniorforskere, og konkluderer, at disse uligheder med fordel kan identificeres gennem autoetnografisk analyse.

\section{AUTOETNOGRAFI SOM DEKOLONIAL METODE OG VIDENSPRODUKTION}

Autoetnografi nyder i disse dage stigende popularitet som dekolonial forskningsmetode. Den refleksive og selvundersøgende metode er ifølge Dutta $(2018,95)$ et ideelt værktøj til kritisk at undersøge 'magt-terræner' og til at åbne nye muligheder for modstand gennem selvfortælling.

Den autoetnografiske forskningsmetode har tre bemærkelsesværdige styrker, som er særligt vigtige for kritisk forskning om minoritetsbeskatning. Den første styrke er forandringspotentialet i autoetnografien, den anden er metodens specifikke modstandspotentiale i mødet med hvidhed, og den sidste er metodens relativt lave materielle og følelsesmæssige ressourcekrav.

I forhold til den første styrke, autoetnografiens forandringspotentiale, har forskere som Dutta vist, at autoetnografisk forskning skaber et muligheds- eller vidensrum mellem individuel og kollektiv videnspraksis. Dutta kalder dette det "tredje space" (Dutta 2018, 95). Når jeg anvender den autoetnografiske metode insisterer jeg derfor på at vidensproduktion fra erfarede og situerede minoriserede positioner kan gavne det danske forskningsmiljø, ligesom vi har set det være tilfældet i mange andre kontekster (Dutta 2018; Robinson og Clardy 2010; Mainsah og Prøitz 2015). Den anden styrke består i autoetnografiens specifikke potentiale i mødet med hvidhed. Med reference til Satoshi Toyosaki viser Dutta hvor effektivt autoetnografiens narrative og affektive potentiale kan indfries, når den bruges til at nå ind til nogle kerneoplevelser i mødet med hvidhed i akademia. Én af Toyosakis kerneargumenter kan siges at være, at vi aldrig kan adskille os selv (auto) fra den kultur eller gruppe (etno) som vi undersøger (grafi):

(...) Satoshi works through decolonization to unsettle the postcolonial turn in autoethnography, simultaneously voicing our complicit location within academic structures and our resistive strategies that are ongoing sites of transformative articulations. His suggestion that "autoethnography does not signify a de- 
parture from the "what" it critiques; it is always departing, yet never completely" guides us toward a practice of deep reflexivity as an ongoing interrogation of the privileges we occupy as scholars/critics. (Dutta 2018, 95)

Heri ligger kernen af den autoetnografiske metode for mig; forståelsen og analysen af min egen deltagelse, komplicitet og konstituerende rolle i det akademiske miljø, som denne artikel forsøger at undersøge. Den tredje og sidste styrke, som den autoetnografiske metode har, er, at den bidrager både til økonomiske og tidsmæssige besparelser, og især til at begrænse yderligere beskadigelse og beskatning af allerede udsatte minoritetspersoner. Når jeg kan skrive fra min egen position, belaster jeg ikke mine kolleger yderligere med det affektive arbejde, som en gensidig validering af hinandens oplevelser fordrer. Metoden er med andre ord mere omkostningslav, end hvis jeg eksempelvis havde udfort en interview-baseret eller observationsetnografisk undersøgelse af minoritetsbeskatning i mine forskningsmiljøer, hvor andre minoriserede personer havde været subjekterne, jeg skrev om.

Når jeg som filmforsker bevæger mig ud $i$ at skrive om minoritetsbeskatning, er det en slags udtryk for minoritetsbeskatning af mig. Da lignende forskning indtil nu har været stærkt begrænset i danske sammenhænge, er artiklen samtidig et udtryk for, at jeg, qua min position som racialiseret minoritetskvinde i dansk forskning, har en privilegeret adgang til hvad Haraway (1988) ville kalde situeret viden, som forskere, der ikke er dobbelt-marginaliserede som jeg, måske ikke har adgang til. Samtidig er afvigelsen fra mit forskningsfelt til at undersøge minoritetsbeskatning, ligesom mit fokus i filmforskningen på minoritetsrepræsentation, begge udtryk for tokenisering, som er en central del af den minoritetsbeskatning, jeg vil uddybe i det kommende afsnit (Padilla 1994; Canton 2013).

Jeg trækker på Toyosaki et als (2009) forståelse af autoetnografisk metode som delvist defineret af en skrivepraksis og rapporteringspraksis som centraliserer en dybdegående bearbejdning af omsorg, følelsesmæssig ærlighed og medfølelse. Dette skift fra en iføge Toyosaki mere stringent tilstræbelsesvis 'objektiv' beskrivende stil, viser Toyosaki et al måske bedst gennem deres fremhævning af Goodall i følgende citat:

Paying special attention to the "writing/reporting” body, Goodall $(2000,31)$ calls for a new set of criteria for new ethnography: evocative, empathetic, caring, therapeutic, emotionally honest, and compassionate. Conventionally speaking, academic writers write to "report" discoveries; however, Goodall advocates that in the new ethnography, writing itself becomes a site of discovery, and hence, a research method. (Toyosaki et al. 2009, 5758)

Siden jeg påbegyndte mit $\mathrm{PhD}$-forløb, har jeg altså ført en logbog med autoetnografiske noter. I den har jeg udfyldt periodiske oplevelser, nogle gange med ordrette citeringer (når jeg f.eks. var heldig at sidde med computeren fremme) - andre gange $i$ notatform baseret på hvad jeg huskede (f.eks. dagen efter julefrokosten med mine kollegaer). Min metode er dermed ikke systematisk planlagt autoetnografisk, men trækker også på memory-arbejde, samt genopdagelsen af momenter, som ikke kunne markeres, nævnes eller beskrives retvisende på tidspunktet, det blev nedfældet, eksempelvis fordi jeg manglede ord for dem, eller fordi jeg ikke altid forstod en oplevelse som diskriminerende, før jeg huskede den ved senere lejlighed. Vi kan sjældent genkende de undertrykkende koloniale strukturer, vi er en del af. I mit tilfælde lå en del af opdagelsesarbejdet, ligesom for Toyosaki og Goodall, derfor i den efterfølgende skriveøvelse. På denne måde er de autoetnografisk-metodiske begrænsninger og valg (eksempelvis rekonstruerende arbejde) en nødvendig følge af dekolonialt 
arbejde med autoetnografi. Artiklen er bygget på det, Heewon Chang (2016) i sin bog Autoethnography as Method, kalder 'memory-data' og 'reflective data', snarere end eksempelvis 'external data'.

Det er ikke altid muligt at rapportere og beskrive retvisende, når man ikke ved, hvad man leder efter, har begreberne til at beskrive eller når man har været udsat for eksempelvis mikro-aggressioner. Hvis man er vokset op med normalisering af $\mathrm{N}$-ordet, kan det tage lang tid, før man opdager, at det måske ikke hører hjemme i universitetssammenhænge. Traditionelle videnskabelige regler kan altså medvirke til, at kritisk situeret viden ties ihjel. For eksempel kan jeg ikke altid garantere korrekt citering, og må i nogle tilfælde nøjes med rekonstruktioner, fordi jeg ikke fik skrevet ned ord for ord, hvad nogen sagde til julefrokosten. Ligeledes kan mine anonymiserede observerede kollegaer træde frem og underminere validiteten af $\mathrm{min}$ oplevelse og min måske ukomplette rapportering af samme hændelser. Denne slags tvivlslåen vil være med til at fastholde en vidensproduktion som typisk udelukker denne slags historier. Allerede her begynder den beskatning denne artikel behandler at vise sig: som marginaliseret eller minoriseret i dansk akademia takseres jeg, hvis jeg ønsker at dokumentere egne oplevelser af uligheder i systemet, med at skulle kortlægge hændelser, som jeg måske ikke har lyst til, eller mulighed for, at kunne kortlægge tilfredsstillende for normativ (hvid, vestlig, patriarkalsk, ableistisk, klasset) videnspraksis.

\section{MinORiteTsbesKatNing}

Begrebet minoritetsbeskatning krediteres Amado Padilla (Canton 2013; Joseph et al. 2011; Padilla 1994). Cecil Cantons udlægning af Padillas definition illustrerer begrebets rod som en beskatning af racialiserede fakultetsmedlemmer:

He defined "cultural taxation" as the obliga- tion to show good citizenship towards the institution by serving its needs for ethnic representation on committees, or to demonstrate knowledge and commitment to a cultural group $(. .$.$) .$

This "cultural taxation" phenomenon, as stated earlier, is the price that most faculty of color must pay for admission to and retention in the Academy. "Cultural taxation" is a stealth workload escalator for faculty of color. (Canton 2013)

Canton (2013) opsummerer, at den slags beskatning, der behandles af Padilla typisk drejer sig om ekstra-arbejde i forbindelse med støtte af studerende, samt en forpligtelse til at forske i de minoritets-miljøer, man selv ses som representant for, eller måske endda er ansat til at representere (Canton 2013; Jacobs, Cintrón and Canton 2002).

Jeg oversætter begrebet til minoritetsbeskatning i stedet for kulturel beskatning for at klarlægge, at beskatningen påvirkes af magtrelationer, der minoriserer. Kultur kan forstås som et relativt og et neutralt begreb (vi besidder alle kultur, vi 'gør' alle kultur). Ved at bruge minoritet i stedet sikrer jeg, at begrebet kun anvendes i sammenhæng med magtudøvelsen: minorisering. Ydermere undgår jeg at bidrage til at kultur bruges som et indforstået proxy-begreb for forskellighed. I Danmark har kultur (og 'kulturforskelle') vist sig at være et racialiserende begreb, der bruges som erstatning for race, men har samme funktion; at adskille 'os' fra 'dem' (Hervik 1999).

Forskningen i minoritetsbeskatning rækker vidt, fra studier i ekstra-belastningen af mødre i akademia (Castaneda og Isgro 2013; Drummond 2014; Connelly og Ghodsee 2011; Young 2015), henover studier af minoriteter i akademia (Nelson et al. 1997), specifikke studier om sorthed i akademia (Bonner et al. 2015; Shavers et al. 2015) og ind i intersektionelle studier af de specifikke minoritetsbeskatninger, der ram- 
mer folk, som eksempelvis både er udsat på køn og racialisering (Joseph et Al. 2011; Niles et al. 2011; Hirshfield et al. 2012; Gutiérrez y Muhs et al. 2012). ${ }^{1}$

Mange studier i minoritetsbeskatning, især dem med primært fokus på racialisering og som er tættest på Padillas definition, tager udgangspunkt i en relativt konkretisérbar og målbar form for ekstraarbejde, som typisk knyttes til en stolthed over eller et tilhørsforhold til den institution, man er ansat ved (Padilla 1994; Canton 2013; Shavers et al. 2015). Denne slags beskatninger kunne eksempelvis tage sig ud som deltagelse i paneler, oplæg og works- hops, som specifikt positioneres omkring éns rolle som minoritet (eksempelvis paneler om diversitet på universitetet). Nyere analyser anskuer imidlertid også minoritetsbeskatning som en emotionel, eller affektiv (Ahmed 2012), beskatning af fakultsansatte, der belastes igennem ekstra mentor- og støtte arbejde for studerende, både i forhold til konkret vejledning og karrierevejledning, men også i forhold til emotionel støtte og pædagogik $\mathrm{i}$ en hvid institution samt i deres arbejdsrelationer til kollegaer ved samme institutioner (Niles et al. 2011; Joseph et al. 2011; Bonner et al. 2015).

Sara Ahmed's (2012) konceptualisering

\section{MINORITETSBESKATNING}

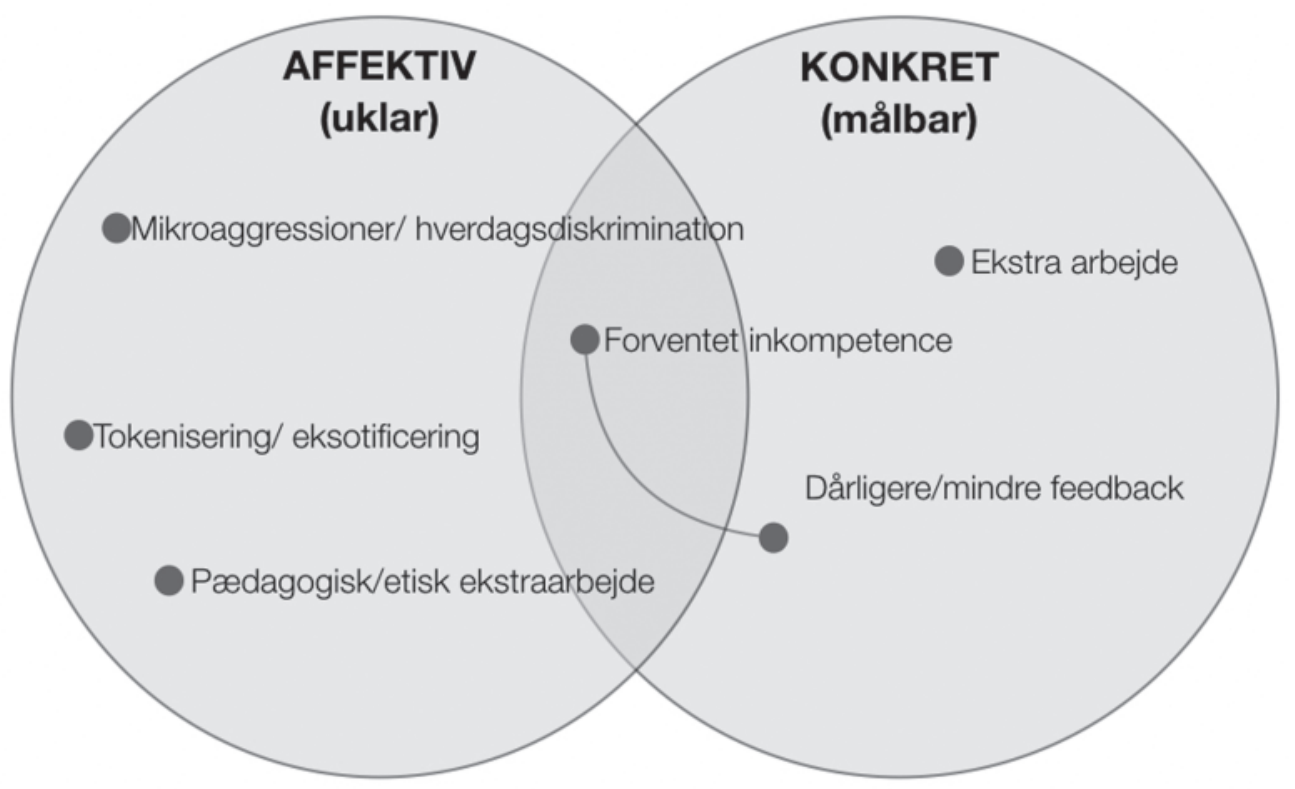

Illustration af Tess S. Skadegård Thorsen, 2018

Illustration af minoritetsbeskatning kortlagt efter de affektive (ofte skjulte og uklare) former for taksering overfor de konkrete (og ofte let mailbare) typer af taksering. Overlappet af de to cirkler viser, at typerne af minoritetsbeskatning kan hange sammen og/eller falde i begge kategorier. Mine eksempler på forventet inkompetence og därligere feedback viser, at de to i mine tilfalde hanger sammen - derfor trekkes en streg $i$ illustrationen mellem punkterne. Der kan givetvis vere mange flere tilfalde, hvor de forskellige punkter informerer hinanden ved brug af nyt analyse-materiale. 
af diversitetsarbejde (diversity work), som et målrettet eller intentionelt arbejde med diversitet er et godt udgangspunkt for den slags opgaver (og arbejdsbyrde), der kan være tale om med minoritetsbeskatning. Ahmeds konceptualisering rummer både det affektive arbejde, som jeg vil komme ind på sidst i artiklen, samt det konkrete arbejde (der kan gøres op i timer og minutter), der ligger i eksempelvis at læse sig ind i litteraturen omkring racialisering, diskrimination, $\mathrm{k} ø \mathrm{n}, \mathrm{mm} \cdot{ }^{1}$

Saledes kan man tale om adskillige former for minoritetsbeskatning, spredt på tværs af undertrykkelsesakser (abilitet, 'race', nationalitet, køn, klasse, seksualitet, $\mathrm{mm}$.), og i variationer fra de konkretisérbare og målbare henover de mere skjulte og affektive. Jeg fokuserer i denne artikel på de komplekse og nuancerede dynamikker, der typisk ville falde udenfor lovens rammer (herunder hadforbrydelser, juridisk diskrimination/forskelsbehandling og chikane), men disse kunne eventuelt også tælles med. Med mit fokus argumenterer jeg for, at minoritetsbeskatning også er et spørgsmål om de små, og ofte mere nuancerede, strukturelt diskriminerende praksisser (Skadegård 2014; 2017), vi kender fra farveblind racisme (Bonilla-Silva 2003), hverdagracisme (Essed 1990) og hverdagssexisme (Bates 2016).

I de følgende afsnit vil jeg gennemgå eksempler på typer af minoritetsbeskatning. Jeg følger Joseph og Hirshfields (2011) fortolkning af Padillas (1994) definition, hvori de især lægger vægt på udvidelsen af den typiske forståelse af minoritetsbeskatning som et spørgsmål om ekstra arbejde, til også at tælle den ekstra affektive og emotionelle belastning. Jeg opdeler derfor de følgende eksempler i to kategorier, som, til trods for adskillige sammenhænge og overlap, adskilles for klarheds skyld. Først gennemgår jeg de konkretisérbare beskatninger. Dernæst undersøger jeg eksempler på affektiv og/eller emotionel minoritetsbeskatning. Opdelingen er et illustrativt (men ukomplet) forsøg på at påpege, at minoritetsbeskatning både drejer sig om reel taksering af marginaliserede forskeres arbejdstid og dermed avanceringsmuligheder, men også en skjult beskatning vi aldrig vil kunne få et fuldt overblik over.

\section{KONKRETISÉRBAR BESKATNING}

Litteraturen om minoritetsbeskatning er mest fyldestgørende, når det drejer sig om den slags beskatning, man kan måle på det jeg kalder konkretisérbar beskatning (Padilla 1994; Canton 2013; Shavers et al 2015). Dette afspejler måske en tendens til at belastningen af arbejdere $i$ akademiet oftest gøres op i tabt arbejdskraft gennem cost-benefit analyser. Af samme årsag begynder jeg med eksempler på den målbare og konkretisérbare beskatning, men lægger mest vægt på den affektive eller ikke-målbare beskatning. De to eksempler, jeg giver på konkretisérbar minoritetsbeskatning i dette tilfælde, omhandler 'ekstra ubetalt arbejde' samt 'mindre/dårligere feedback'. Begge kategorier er kun eksempler på former for konkretisérbar beskatning, som jeg har opdaget påvirker min egen vej igennem mit akademiske arbejde. Der er givetvis langt flere eksempler, både dem, jeg endnu ikke har opdaget fra mit eget tilfælde, samt dem, som andre minoriserede akademikere oplever, men som jeg er foruden grundet min priviligerede (cis-, dansktalende, engelsktalende, 'nordiske', kropskapable, $\mathrm{mm}$.) position.

\section{EKSTRA UBETALT ARBEJDE}

Udgangspunktet for 'minoritetsbeskatning' er en tese om, at minoritetspersoner i akademiet 'beskattes' med ekstraarbejde, som de ikke lønnes for, men forventes at udføre som en del af deres ansættelse i kraft af deres position. Der er ikke tale om opgaver, som specificeres ved ansættelse, registreres, ej heller opgaver som nødvendigvis vil hjælpe en eventuel avancering i det akademiske 
hierarki (Padilla 1994). ${ }^{2}$ Padillas definition rummer altså adskillige former for ubetalt ekstraarbejde, som inkluderer følgende eksempler fra mit eget virke: et gratis oplæg jeg afviklede for en frivillig organisation, og en gratis forelæsning jeg afviklede på en senior-kollegas kursus. Fælles for eksemplerne er, at begge var blevet afholdt hvad end jeg havde sagt ja til dem eller ej. Med andre ord ville der givetvis være nogen udover jeg selv - som var villig til og interesseret $\mathrm{i}$ at indtage den position/plads, jeg blev tilbudt. I begge tilfælde var mit første spørgsmål i afvejelsen af om jeg 'havde råd' til at bruge de ubetalte timer på det derfor: hvem vil gøre det, hvis ikke jeg gør?

Shavers et al. (2015) har argumenteret for at Brayboys (citeret i Shavers et al. 2015 ) begreb 'hidden service agendas' kan være rammende for det dilemma, man som minoriseret akademiker stilles $i$, når man inviteres til at deltage $i$ et panel som det eneste minoriserede medlem. De argumenterer for, at en del af den interne forhandling af éns deltagelse kan have at gøre med, om man på den ene side oplever, at man 'tokeniseres’ (dvs. føler sig udvalgt på baggrund af og til at repræsentere en bestemt minoritetsgruppe), og på den anden side skal afveje om panelet uden én vil være endnu et tilfælde af udviskning (ibid.).

Foruden min frygt for at skuffe eller afskrække hvide organisatorer og seniorforskere fra at ville arbejde med mig igen, afhang min beslutning om at deltage i begge tilfælde forst og fremmest af afvejelsen af min mulige tokenisering overfor risikoen for, at min position ellers ville indtages af ikke-minoriserede personer - altså at jeg ved ikke at deltage ville bidrage til min egen udviskning.

\section{MINDRE ELLER DÅRLIGERE FEEDBACK}

Undervejs i danske ph.d.-forløb deltager de fleste studerende i diverse obligatoriske og valgfrie ph.d.-kurser. Ofte oplevede jeg til disse kurser at blive bedt om at legitimere eller redegøre for relativt elementære spørgsmål om præmissen for min forskning, især $\mathrm{i}$ forhold til min positionalitet. Jeg oplevede imidlertid jævnligt at mine hvide og/eller mandlige ph.d.-medstuderende ikke forventedes at redegøre for deres positioner på samme måde eller i lige så høj grad.

Til ét kursus blev jeg, efter at have præsenteret mit arbejde mundtligt og skriftligt, spurgt af en seniorforsker inden for medieforskning, om jeg havde overvejet, om det blot var en "formodning", at der var et "problem med representation i dansk film", og om mere repræsentation er nødvendig, eller nødvendigvis er en god ting (Logbog 2016). Da jeg havde dokumenteret præmissen for min forskning i lige så høj grad som de andre deltagere på kurset var det bemærkelsesværdigt, at jeg var dén studerende, for hvem præmissen blev den største bremseklods for kvalitetsfeedback.

Begrebet 'forventet inkompetence' (presumed incompetence; Gutiérrez y Muhs et al. 2012) italesætter de underliggende dynamikker i en situation som den førbeskrevne og åbner op for en nuanceret forståelse af den. Fokus flyttes fra 'intentioner', der altid er debatérbare, til de effekter, disse dokumenterede handlinger har: i dette tilfælde er effekten, at jeg, modsat andre kursusdeltagere, forventes at besvare et elementært og grundlæggende spørgsmål.

Når jeg stilles denne slags spørgsmål sker to ting. Først og fremmest koster det mig tid i forhold til den reelle feedback, jeg får. Til mange ph.d.-kurser struktureres tiden således, at deltagere får tildelt et tidsrum til sparring på deres forskning. Når den første del af min feedback skal bruges på at forhandle legitimiteten og præmissen for mit forskningsspørgsmål på grund af min position, og fordi min forskning omhandler noget politiseret som race, køn og repræsentation (hvor min krop automatisk læses som en del af denne politisering), mister jeg kostbar tid til feedback på min analyse, anvendelsen af teori og behandling af mine data. 
Dernæst bidrager et sådant spørgsmål, uanset hvordan det er intenderet, til at andre i rummet kan forvente, at jeg er inkompetent (eller mindre kompetent), fordi jeg implicit forventes ikke at have gjort et grundigt (eller kompetent) nok arbejde i at behandle de elementære eller introducerende spørgsmål til min egen forskningspraksis (Gutiérrez y Muhs et al. 2012).

\section{AFFEKTIV BESKATING}

I 2011 udvidede Joseph og Hirshfield (2011) Padillas definition gennem et fokus på de nuancerede og til tider uhåndgribelige minoritetsbeskatninger, der typisk berører interaktioner og emotionelle/affektive forbindelser mellem marginaliserede akademikere og eksempelvis kollegaer, studerende og administrativt personale. I de følgende tre eksempler vil jeg fokusere på mine oplevelser af samme afart af affektive, emotionelle, komplekse og uhåndgribelige former for minoritetsbeskatning.

\section{MikroAgGressioner/}

\section{HVERDAGSRACISME}

Når jeg fortxller om min forskning til en kollega, og hun forklarer, at hun har en mellemøstlig ven, som er blevet spyttet efter på gaden, fordi han er muslim - og hun så siger, at hun ikke ved, hvordan hun skal få ham til ikke altid at være så voldsom og radikal i sine udmeldinger om diskrimination. Han påtager sig sådan en offerrolle, og det er rigtig svært at få ham til at være konstruktiv i stedet for vred hele tiden. Og så spørger mig, hvilke film jeg ser på - er det mon en af Hella Joofs?" (Anonymiseret Logbog, 2016)

Eksemplet fra mit første møde med en kollega i frokoststuen på mit arbejde, som velintenderet og nysgerrigt spurgte til min forskning, viser hvordan mødet med hverdagsracisme og konfrontationer med racialiseret vold hverken behøver at være motiveret eller tilsigtet. Som Skadegård (2014;
2017) og Bissenbakker og Myong (2013) har illustreret, er strukturel diskrimination og racialiseringsprocesser ikke direkte afhængige af intention eller vilje. Denne kollega var én af mange, som jævnligt deler deres eksempler på racisme med mig. I dette tilfælde handlede fortællingen om en tilfældig "mellemøstlig ven", der oplever racistisk vold. Fælles for denne slags udvekslinger er, at jeg qua min position som minoriseret og marginaliseret forsker, beskæftiget med en marginalisering, der er direkte knyttet til min egen, ofte findes i den modtagende ende af fortællinger om voldelig racisme. Ydermere forventes jeg at kunne reagere på, eller måske endda fagligt vurdere racismen, uden hensyn til at disse eksempler potentielt kan have en specifik virkning på mig netop i kraft af min position.

Når jeg i utilsigtet diskriminerende hverdagssituationer afkræves en reaktion, kan jeg vælge at reagere med passiv accept (og dermed meddelagtighed i) racisme eller med at indtage den nødvendige glædesdræberposition, som ekspert i racisme og som racialiseret minoritet, og forklare de raciale implikationer i min fremmede kollegas fortælling. Dette valg kompliceres selvfølgelig yderligere når dynamikken sker på tværs af magtforhold. Muligheden for at sige fra bliver eksempelvis yderligere indsnævret, når personen arbejder tættere sammen med mig, og er en bekendt overordnet kollega. Som i dette tilfælde: over kaffe blev jeg bedt af en overordnet kollega om ikke at bruge 'vi' som en fællesbetegnelse om danskere, der havde medvirket til slavehandel og slavegørelse. Som kollegaen forklarede: "Jeg har aldrig haft slaver". Samme kollega fortsatte med en sammenligning af stavnsbåndet og slaveriet (rekonstruktion udfra logbog 2016).

I en anden situation talte jeg med en mindre gruppe minoriserede kollegaer om kritiske spørgsmål, vi ofte mødes med omkring vores position og dennes mulige påvirkning af vores praksis. Vi blev kort efter afbrudt af en seniorforsker, som ivrigt 
fremlagde argumenter for at dette ikke er en specifik dynamik for racegjorte minoriteter, men også er noget hvide forskere udsættes for. ${ }^{3}$

Uanset om der er tale om sammenligninger mellem hvide europxiske underklasser og kolonial slavegørelse eller mellem majoriserede og magtfulde forskeres oplevelser og minoriserede junior-forskeres, er sammenligningsdynamikken med til at udviske racialiseret magt og videreføre farve-blind hverdagsracisme (Bonilla-Silva 2003; Essed 1990).

Den primære beskatning i disse øjeblikke handler ikke om direkte eller håndgribelig racisme, men om at jeg forventes at forholde mig til racisme og vurdere eksempler på racisme, som var de neutrale, når de ikke er det. Sammenligningerne er, i sig selv, voldelige, netop fordi de er sammenligninger, og dermed formoder en ligestilling mellem oplevelser og mellem positioner. Effekten af sammenligningen mellem min oplevelse som marginaliseret akademiker og en eksempelvis hvid akademiker er, at jeg italesættes ud fra en præmis om, at jeg er problemet, fordi jeg ikke blot haindterer min situation, ligesom de håndterer deres.

These violent remarks reveal the inadequacy of dominant scholarship to relate not only to marginalised subjects, but also to our experiences and discourses. They perform a fruitful combination of power, intimidation and control which succeeds in silencing oppressed voices. Fruitful indeed, for after this last episode I remember I stopped writing for more than a month. I became temporarily voiceless. I had a whiteout, was waiting for a Black-in. (Kilomba 2012, 6)

Grada Kilomba illustrerer i ovenstående citat, at det vigtigste spørgsmål ikke er, om disse eksempler er udtryk for vold eller marginalisering, men hvad disse eksempler gør ved (dobbelt-, eller multi-) marginaliserede forskere som os. Fordi éns forskning, men også éns oplevelser og position, kon- stant er til forhandling. Dette er bogstaveligt talt udmattende, og man mister stemmen. Kilomba stopper med at skrive. Jeg begynder at skrive om mine oplevelser i stedet for min forskning. Effekten er den samme. Beskatningen har forsinket og drænet os - og vi var allerede (forventet) bagude (Gutiérrez y Muhs et al. 2012).

\section{TOKENISERING/EKSOTIFICERING}

Udfordringerne omkring den affektive minoritetsbeskatning findes også i de positive, opbakkende og formodede allierede interaktioner, vi møder.

I ét tilfælde skulle jeg undervise med en langt mere erfaren (og mig overordnet) kollega. Vi skulle undervise i emner relateret til 'race', undertrykkelse, mm., og efter forelæsningen fortalte kollegaen mig, at det var en fornøjelse at undervise med mig, fordi jeg "bragte legitimitet" til undervisningssituationen (Logbog 2016). Jeg svarede, at jeg havde det på samme måde - en hvid seniorforsker bragte også legitimitet til min undervisning. Vi grinede af mit svar, men jeg forlod interaktionen og undrede mig - var jeg en god underviser, eller var jeg en god brun underviser? Hvorfor havde de (hvide) studerende kigget til min kollega, når jeg havde sagt noget kontroversielt - og hvorfor havde min kollega skullet nikke med hovedet for at bekræfte, at det var korrekt, hvad jeg sagde?

Den tokenisering eller eksotificering, man kan opleve som positiv eller som et kortvarigt humoristisk helle, er altså tæt knyttet med den komplekse dynamik, man som marginaliseret underviser kan møde i klasselokalet. Man forventes at undervise hvide studerende om race, men undermineres af dem, fordi det gøres fra en markeret position (Toyosaki et al. 2009, 62).

I danske sammenhænge, hvor synlige minoriteter udgør en marginal del af forskningsmiljøerne omkring køn og race, er rollen som 'glædesdræber' (killjoy; Ahmed 2012) uundgåelig for forskere som jeg. 
Nogle gange vælger jeg at indtage positionen - eksempelvis når jeg er den eneste, der siger fra overfor et næsten helt hvidt panel fra det globale nord, som taler om det globale syd på ét af mine ph.d.-kurser, hvor jeg er en af meget få personer, der kan identificeres som ikke-hvid og med rødder i det globale syd (logbog 2017). Andre gange gøres man, uden selv at have valgt det, til ufrivillig glædesdræber:

Til endnu en julefrokost - hvor vi laver tour de chambre - min telefon ringer - jeg træder ud af rummet og det er hurtigt overstået - da jeg vender tilbage overhører jeg en senior-forsker lave en joke med N-ordet - jeg undrer mig resten af aftenen om hun havde ventet med joken til jeg var ude af rummet. (rekonstruering fra logbog 2017)

Om min tilstedeværelse rent faktisk havde indvirkning på brugen af $\mathrm{N}$-ordet er ikke det centrale spørgsmål i denne sammenhæng. I relation til minoritetsbeskatning er det umiddelbare spørgsmål snarere hvorvidt tvivlen omkring min rolle som glædesdræber kan ses som en ekstra belastning af mine sociale interaktioner på arbejdspladsen (Ahmed 2012). Normalt bruges glædesdrab om en aktiv handling. Er min blotte tilstedeværelse nok til at dræbe 'humoren'?

\section{PæDAGOGisK/ETISK EKSTRAARBEJDE}

Jeg kontaktes jævnligt af studerende og kollegaer med ønsker om vejledning og rådgivning, selvom de vejledes af andre undervisere end jeg selv. Dette er typisk praksis i akademiet, og jeg har selv benyttet mig af ubetalt vejledning og rådgivning fra forskere, som ikke var officielt tilknyttet mine projekter. Ikke desto mindre spillede min dobbelte marginalisering i nogle tilfælde en rolle for den beskatning, dette arbejde medfører.

På den ene side er der tale om et eksempel på konkret beskatning, hvor jeg bruger ekstra tid på gratis at vejlede kollegaer og studerende, og især på dem der, som jeg, er marginaliserede. ${ }^{4}$ Udover den konkrete taksering, er den specifikke minoritetsbeskatning i de tilfælde, hvor jeg får henvendelser fra minoriserede studerende, også ofte et spørgsmål om affektiv beskatning. Jeg kontaktes nemlig udover almindelige tilfælde med akademiske spørgsmål også, i kraft af min marginalisering, med spørgsmål, der vedrører specifikke udfordringer minoriserede forskere møder. Nogle gange skal jeg forholde mig til den diskrimination og vold, de studerende møder på universitetet, fordi de ikke oplever, at de kan gå til andre medlemmer af det videnskabelige personale med den slags spørgsmål. Uanset om typerne og mængden af spørgsmål selvfølgelig kan afhænge af adskillige andre faktorer, er minoritetsbeskatning her især et spørgsmål om, at jeg ikke ønsker at afvise forespørgsler fra folk, der, som jeg, er minoriserede, fordi jeg ved, at de i forvejen marginaliseres $\mathrm{i}$ akademiet.

\section{KONKLUSION}

Med udgangspunkt i autoetnografi har denne artikel advokeret for anvendeligheden af begrebet 'minoritetsbeskatning' som en dansk adaptering af det amerikanske begreb 'cultural taxation' (Padilla 1994). Minoritetsbeskatning foreslås som et begreb, der kan rumme både de konkretisérbare, målbare og fysiske ekstra-opgaver og byrder, der kan tilfalde minoriserede forskere, samt de affektive, komplekse og svært håndgribelige belastninger, disse kan møde i det danske akademi.

Et centralt element i den autoetnografiske metodetilgang til minoritetsbeskatning er decentreringen af hvidhed og af intention. Snarere end at dvæle ved om diskrimination, ulighed og racisme er tilsigtet, søger analyser af minoritetsbeskatning at dokumentere og undersøge effekterne af uligheder ( $\mathrm{g}$ af forventede eller frygtede uligheder). Som artiklens analyse viser, er 
disse effekter uafhængige af intention eller hvid uskyld, men omhandler blandt andet den udmattelse og usikkerhed, minoriserede forskere belastes med, når de beskattes med at skulle vurdere egen undertrykkelse.

Minoritetsbeskatning dækker således over det konkrete, målbare og komplekse, affektive ekstraarbejde minoriserede mennesker i akademia forventes at udføre eller påføres at udføre grundet strukturelle uligheder. Italesættelsen af dette ekstraarbejde som en beskatning bidrager til en konkretisering af uligheder, som til tider kan være svære at forstå, kvantificere eller forhandle.

Minoritetsbeskatning rummer tilmed de intersektionelle (Crenshaw 1991) nuancer, der er i spil i mødet mellem eksempelvis strukturel diskrimination (Skadegård 2014; 2017), kønsligestilling (Bates 2016) og hverdags-racisme (Essed 1990) på danske universiteter.

\section{Noter}

1. I denne artikel taler jeg ikke yderligere om den slags arbejde, det kræver, når man 'læser sig ind i' felter som dekolonisering eller diskrimination, selvom denne slags opkvalificering givetvis disproportionalt tilfalder minoriserede akademikere. 2. I USA tales der især om deltagelse i paneler, bestyrelser og styregrupper samt tilfælde hvor medarbejdere forventes at repræsentere universitetet i diverse sammenhænge (messer, arrangementer, "talks") (Padilla 1994; Joseph et al. 2011). Typerne af opgaver kunne se anderledes ud i Danmark. Måske lægger det danske akademi mindre pres på medarbejdere til at 'markedsføre' universiteterne, da vores universitetsstruktur (om end i mindre og mindre grad) ikke er lige så privatiseret som i USA.

3. Dette er sket mindst 3 noterede gange i min logbog i møder med forskellige kolleger fra ph.d.til professor-niveau. Alle tre oplevede, at de blev udspurgt om, hvorfor de (som hvide forskere) forskede i marginalisering/undertrykkelse/racisme (af/overfor minoriserede mennesker) - og alle tre forklarede mig, gennem sammenligning, at min oplevelse af deligitimering derfor ikke havde noget specifikt at gøre med min position (da de oplevede, at de ligeledes delegitimeredes).
4. Jeg spurgte til sammenligning en mandlig kollega, der passerer for hvid, og ikke studerer race, og vi opdagede stor diskrepans i mængden af ubetalt arbejde, vi bedes om og siger ja til - jeg var markant mere belastet, især så tidligt i min karriere. Dette mønster kunne med fordel undersøges med en bred kortlægning.

\section{LITTERATUR}

- Ahmed, S. 2012. On being included: Racism and diversity in institutional life. USA: Duke University Press. DOI:

https://doi.org/10.1215/9780822395324

- Bates, L. 2016. Everyday sexism: The project that inspired a worldwide movement. USA: Macmillan. - Berdahl, J. og Moore, C. 2006. Workplace Harrassment: Double Jeopardy for Minority Women. Journal of Applied Psychology. 91(2), 426-436. DOI: https://psycnet.apa.org/doi/10.1037/ 0021-9010.91.2.426

· Bissenbakker, M. og Myong, L. 2013. Love Will Keep Us Together: Kxrlighed og hvid transracialitet i protester mod danske familie-sammenføringsregler. Tidsskrift for kjønnsforskning. 36(03-04), 188-202.

- Bonilla-Silva, E. 2003. Racism without racists: Color-blind racism and the persistence of racial inequality in America. USA: Rowman \& Littlefield. DOI: $10.1177 / 0042085906291929$.

- Bonner II, FA., Marbley, AF., Truitt, F., Robinson, PA., Banda, RM. og Hughes, RK. eds. 2015. Reflective Teaching: Black Faculty in the Academy: Narratives for Negotiating Identity and Achieving Success. New York: Routledge.

- Canton, C. 2013. The 'Cultural Taxation' of Faculty of Color in the Academy. California Faculty Magazine, December 5, 9-10.

. Castaneda, M. og Isgro, K. eds. 2013. Mothers in Academia. New York: Columbia University Press. . Chang, H. 2016. Autoethnography As Method. USA: Routledge.

. Crenshaw, K. 1991. Mapping the margins: Identity politics, intersectionality, and violence against women. Stanford Law Review. 43(6), 1241-1299. . Connelly, R. and Ghodsee, K. 2011. Professor Mommy: Finding Work-Family Balance in Academia. Lanham, MD: Rowman \& Littlefield Publishers.

- Drummond, SB. 2014. Review of Mothers in Academia. Teaching Theology \& Religion. 17(4), 394-395. 
- Dutta, MJ. 2018. Autoethnography as Decolonization, Decolonizing Autoethnography: Resisting to Build Our Homes. Cultural studies, critical methodologies. 18(1), 94-96.

- Essed, P. 1990. Everyday Racism: Reports from Women of Two Cultures. USA: Hunter House. . Gutiérrez y Muhs, G., Niemann, YF., González, CG. and Harris, AP. eds. 2012. Presumed Incompetent: The Intersections of Race and Class for Women in Academia. USA: Utah State University Press.

- Haraway, D. 1988. Situated knowledges: The science question in feminism and the privilege of partial perspective. Feminist studies. 14(3), 575-599.

- Hervik, P. 1999. Den generende forskellighed.

Danmark: Hans Reitzels Forlag.

- Henry, A. 2015. 'We especially welcome applications from members of visible minority groups': Reflections on race, gender and life at three universities. Race Ethnicity and Education. 18(5), 589-610. DOI:

https://doi.org/10.1080/13613324.2015.1023

787.

· Hirshfield, LE. and Joseph, TD. 2012. 'We Need a Woman, We Need a Black Woman': Gender, Race, and Identity Taxation in the Academy. Gender \& Education. 24(2), 213-227. DOI: https://doi.org/10.1080/09540253.2011.6062 08 .

- Jacobs, L., Cintrón, J. and Canton, C. 2002. The Politics of Survival in Academia: Narratives of Inequity, Resilience and Success. USA: Rowman \& Littlefield.

· Joseph, TD. and Hirshfield, LE. 2011. 'Why Don't You Get Somebody New to Do It?' Race and Cultural Taxation in the Academy, Ethnic and Racial Studies. 34(1), 121-141. DOI: https://doi.org/10.1080/01419870.2010.4964 89.

- Kilomba, G. 2012. Africans in the Academia: Diversity in Adversity. Kritische Migrationsforschung. 299-304.

- Mainsah, H., and Prøitz, L. 2015. Two journeys into research on difference in a Nordic context: a collaborative auto-ethnography. In: Andreassen, R. and Vitus, K. eds. Affectivity and Race. Studies from Nordic Contexts. USA: Routledge, 169-186.

- Nelson, S., Pellett, G. and Thigpen, L. 1997. Shattering the Silences: The Case for Minority Faculty. San Francisco, CA: California Newsreel. - Niles, MN. and Gordon, NS. eds. 2011. Still Searching For Our Mothers' Gardens: Experiences of New, Tenure-Track Women of Color At 'Majority' Institutions. Lanham, MD: University Press of America.

- Padilla, A. 1994. Ethnic Minority Scholars, Research, and Mentoring: Current and Future Issues. Educational Researcher. 23(4), 24-27.

- Robinson, CC., and Clardy, P. eds. 2010. Tedious journeys: Autoethnography by women of color in academe. USA: Peter Lang.

- Shavers, MC. and Butler, YE. 2015. Cultural Taxation and the Over-Commitment of Service at Predominantly White Institutions. In: Bonner II, FA., Marbley, AF., Truitt, F., Robinson, PA., Banda, RM., og Hughes, RK. eds. Reflective Teaching: Black Faculty in the Academy: Narratives for Negotiating Identity and Achieving Success. New York: Routledge.

- Skadegård, MC. 2014. Strukturel diskrimination i hverdagen. I: Bilfeldt, A., Jensen, I. og Andersen, J. red. Rettigheder, empowerment og laring. Danmark: Aalborg Universitetsforlag, 160-183.

- Skadegård, MC. 2017. With friends like these, who needs enemies? Structural discrimination and good intentions in everyday interactions. Nordic Journal of Migration Research. 7(4), 214-223. DOI: https://doi.org/10.1515/njmr-2017-0033. - Toyosaki, S., et al. 2009. Community autoethnography: Compiling the personal and resituating whiteness. Cultural Studies, Critical Methodologies. 9(1), 56-83. DOI:

https://doi.org/10.1177/1532708608321498. - Young, AM. ed. 2015. Teacher, Scholar, Mother: Re-Envisioning Motherhood in the Academy. Lanham, MD: Lexington Books. 